\title{
THE NATURE OF THE VERACERVIX OR NECK REGION IN INSECTS.*
}

By G. C. Cralipton, Ph. D.

Occasional references to the neck as the "labial or microthoracic segment" in recent entomological literature indicate a tendency to revive the old mistaken conception of the neck region of insects as representing the labial segment, or a vestigial segment of the thorax ("microthorax")--a view which dates from the time of Strauss-Duerkheim, 1828, and Huxley, 1885 , but for which no real evidence has ever been adduced. It is a simple matter to demonstrate (1) that the neck region is in every way homologous with the other intersegmental regions between the true thoracic segments, and therefore cannot represent a segment at all; (2) that like the other intersegmetal regions with which it is homologous, it has no ganglia or any other segmental structures, either in the adult or embryonic stages; (3) that the labium is not its appendage; and (t) that there is already present in the head capsule a labial segment forming that portion of the head region to which the labium is articulated, while the labium is not articulated to the neck plates at all, the latter being formed behind the true labial segment. If these facts were known, there could be no excuse for arbitrarily designating the neck plates as "the labial or microthoracic segment," without giving any reason for justifying such a course of procedure, in the face of the overwhelming evidence that the neck region does not represent such a segment at all; so that it may perhaps be worth while to present the evidence which completely disproves the view that the neck region is a segment either labial or "microthoracic."

The evidence to be adduced from comparative anatomy in regard to the intersegmental nature of the neck plates, is most convincing and conclusive. In Fig. 1 the intersegmental plates located in the intersegmental regions designated as "Int" (i. e. regions I, III and V) are shaded so as to enable one to compare them more readily in the different segments, the entire figure being a composite of the conditions found in the most primitive of the Apterygotan and Pterygotan

* Contribution from the Entomological Laboratory of the Massachusetts Agricultural college, Imherst, Mass. 
insects. It is at once apparent from a glance at Fig. 1, that the two ventral prothoracic intersegmental plates designated as " $p s$ " in intersegmental region I (i. e. "Int. I") are in every way homologous with the two ventral metathoracic intersegmental plates designated as " $p s$ " in intersegmental region $V$ (i. e. "Int. V"). In the Plecopteron Capnia (Fig. 1) there are two ventral prothoracic intersegmental plates " $p s$ " in intersegmental region I, but in the closely related Plecopteron Leuctra (Fig. 3) the anterior one of the two ventral prothoracic intersegmental plates " $p s$ " has almost disappeared in region I, while

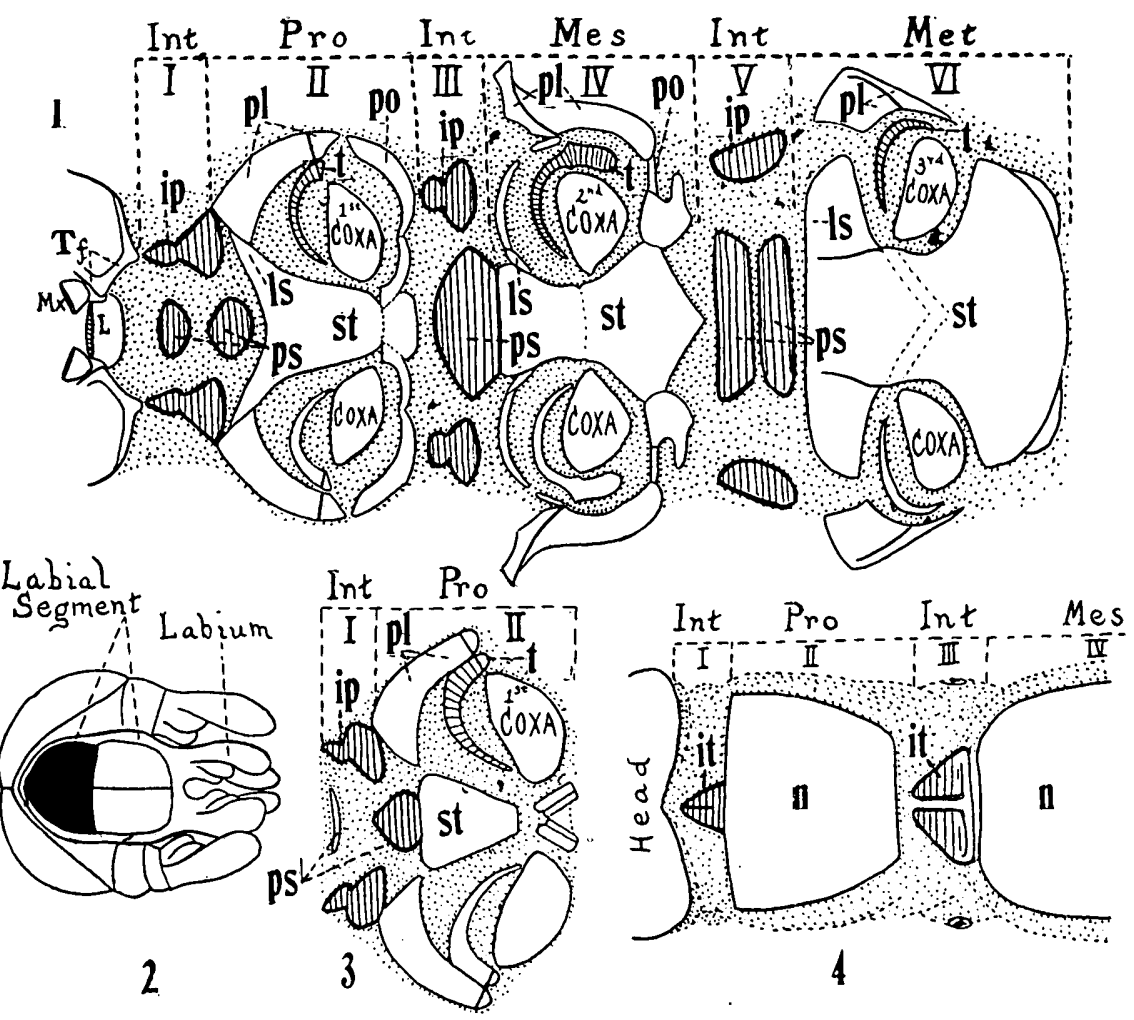

Fig. 1. Lateral and ventral region of the prothorax of Capnia, the mesothorax of Eosentomon, and the metathorax of Japyx drawn as though spread out in one plane. Based, in part, upon figures by Prell, 1913, and Verhoeff, 1904.

Fig. 2. Head of an embryo of Eutermes, stage "F," taken from Fig. 28, Plate: 3, of paper by Holmgren, 1909. (Figure slightly modified).

Fig. 3. Lateral and ventral regions of prothorax of Leuctra, drawn as though spread out in one plane.

Fig. 4. Dorsal view of prothorax and mesothorax of Japyx, based on figures from various sources. 
the posterior one, "ps," is still large, and is connected with the sternal plate "st" behind it, as is the case with the ventral mesothoracic intersegmental plate "ps" of intersegmental region III, in Fig. 1 . It is thus a very simple matter to homologize the ventral prothoracic intersegmental plates "ps" (i. e. the neck plates) of intersegmental region I of Figs. 3 and 1 , with the ventral mesothoracic and metathoracic intersegmental plates "ps" of intersegmental regions III and V, (Fig. 1). In the same way, the lateral prothoracic intersegmental plates " $i p$ " of region I are homologous with the lateral mesothoracic and metathoracic intersegmental plates "ip" of regions III and $V$ (Fig. 1). Similarly, the tergal prothoracic intersegmental plates " $i t$ " of intersegmental region I (Fig. 4) are homologous with the tergal mesothoracic (and also with "the tergal metathoracic) intersegmental plates " $i t$ " of intersegmental region III, etc. (Fig. 4).

It is thus a very simple matter even for the veriest tyro in the study of comparative anatomy to homologize intersegmental region $I$ (i. e. the neck region) with intersegmental regions III and $V$ (Figs. 1, 3 and 4 ), and if comparative morphology has any meaning at all, intersegmental regions III and $\mathrm{V}$

\section{ABBREVIATIONS.}

Int-Intersegmental regions between labial segment and prothorax; between prothorax and mesothorax; and between mesothorax and metathorax.

ip-Interpleurites, or lateral intersegmental plates.

it-Intertergites, or dorsal intersegmental plates.

L-Labium.

1s-Laterosternite, or lateral plate of sternum.

Mes-Mesothorax.

Met-Metathorax.

$\mathrm{Mx}-\mathrm{Maxillae.}$

$\mathrm{n}$-Notum or tergum.

Pro-Prothorax.

pl-Pleural plate (Eupleuron).

po-Post-coxal plate (Postcoxale).

ps-Intersternites or sternal intersegmental plates, the posterior one being the presternite.

st-Sternum.

t-Eutrochantin.

Tf-Trophifer, or sclerite to which labium and maxillae are articulated.

I-Veracervix, or prointersegment, the first intersegmental region which is largely prothoracic.

II-Remainder of prothorax.

III-Mesointersegment, or second intersegmental region which is largely mesothoracic.

IV-Remainder of mesothorax.

V-Metaintersegment.

VI-Remainder of metathorax. 
must also be considered as representing entire segments, if their homologue, intersegmental region $I$, is taken to represent a distinct segment. Verhoeff, 1902-1903, clearly realized that it was impossible to consider intersegmental region I (i. e. the neck) as a distinct segment, without likewise regarding its homologues, intersegmental regions III and $V$, as representing entire segments also, since all three regions are in every way exactly homologous. Verhoeff, 1904, therefore boldly accepted the consequences of his assumption, and claimed that the thorax actually consists of six segments, terming the intersegmental regions the "microthorax, stenothorax and cryptothorax," and making them the equivalents of the prothorax, mesothorax and metathorax. Embryology, however, affords no evidence of more than three segments in the thorax, nor does the evidence of comparative anatomy give any grounds for considering that these intersegmental regions represent distinct segments, since none of them contains any ganglia or other segmental structures-as was pointed out by Silvestri, 1902, Boerner, 1903, Desguin, 1908, and others-and no recent entomologist has had the courage to claim that the thorax is composed of more than three segments.

Some entomologists, however, ignoring the fact that intersegmental region I (Figs. 1, etc.) is in every way homologous with intersegmental regions III and $\mathrm{V}$, would maintain that intersegmental region I (i. e. the neck region) alone represents a distinct segment, claiming that it is the real labial segment. Since the labium ("L" of Fig. 1) does not articulate with the plates of intersegmental region I, but articulates with the sclerite designated as "Tf" (which contains the real labial segment) in the head capsule, these entomologists are forced to the astonishing conclusion that the labium has become detached from its own segment, and, taking along with it the labial neuromere (or labial ganglion) and other characteristic segmental structures, has migrated "bag and baggage" into the head region, leaving behind it the mere shell of the labial segment in the neck region I! Such a disruption and migration of both internal segmental structures and external appendages, which have in some way become detachec from their proper segment, and have grafted themselves onto another region, is wholly without precedent in the entire realm of Zoology, for never did such an occurrence take place other than in a labora- 
tory grafting experiment, and the mechanism for its accomplishment in nature is utterly incomprehensible. What advantage can there possibly be in rejecting the perfectly obvious, simple and logical explanation of the neck plates as an intersegmental region, similar in every way to the other intersegmental regions of the thorax, and in the place of such a simple explanation, proposing that an unparalleled and unprecedented disruption and grafting experiment has taken place in the labial region alone in all nature, when we know of absolutely no mechanism by which such an operation could be carried out? Always, in the cephalization process, both segment and appendage enter into the composition of the head region, although the appendage may subsequently degenerate, and the segment may become indistinguishably fused with the other segments forming the head capsule.

Since the labium articulates with the head capsule, it is but natural to suppose that the segment which originally bore the labial appendage is included in that region of the head capsule with which the labium articulates, and embryology fully justifies this assumption. As is shown in Fig. 2, which I have adapted from a figure of the embryological development of the head of a Termite by Holmgren, 1909, the entire labial segment of these insects actually enters into the composition of the hear capsule of the developing Termite, and does not remain behind to form the neck plates, while its appendages become disrupted and graft themselves upon the head capsule. Furthermore, the neck plates are unusually well developed in the Termites (which are quite closely related to the Blattids), and if these neck plates really represent the labial segment, the fact would he clearly indicated in the development of these insects; whereas, on the contrary, the researches of Holmgren, $19(9)$, and Heymons, $189.5-19(9) 5$, carried out upon a great range of embryos of very primitive insects, conclusively demonstrate that the labial segment enters into the composition of that portion of the head capsule to which the labium is articulated, and which one would naturally expect, from the manner in which all other appendages are articulated to the segment which originally bore them, instead of unnaturally grafting themselves upon some other region!

On this account, I am inclined to regard as a "lapsus calami" the including of the neck plates in the labial segment 
by Riley, 1904, in his table of the parts of the head of a Blattid embryo. Riley offers absolutely no proof whatsoever, either in his text or figures, for such an assumption, and it is the more inexplicable from the fact that he definitely states that the "pleurite" (i. e. the embryologists' term for pleuron) of the labial segment is in the posterior portion of the embryo's head capsule. The only explanation which suggests itself, is that he must have been unaware of the existence of intersegmental regions III and V (Fig. 1), homologous with the neck plates, and situated between the true segments, in the lower insects, and was thus unable otherwise to account for the presence of the intersegmental plates forming the neck region, unless they were to be regarded as representing the labial segment. Since I have not examined Dr. Riley's material, I do not know what evidence it offered for assuming that the neck plates represent the embryonic labial segment, but, while studying in Berlin, Prof. Heymons allowed me to look over his embryological material, in which I was unable to find any indications whatsoever that the neck plates represent the embryological labial segment; and in view of the direct embryological evidence that the labial segment is included in that portion of the head capsule to which the labium is articulated, I am forced to consider that the including of the neck plates in the labial segment in Dr. Riley's paper, is a minor error in an otherwise extremely carefully conducted and valuable embryological investigation.

I have perhaps laid too great emphasis upon a "side issue" of Dr. Riley's paper simply because, in searching through the appended list of reference works, his is the only recent article I could find, containing original embryological data, in which the neck plates are referred to as the labial segment; and on this account, I have inferred that recent investigators have reference to his work, when they state that there is embryological "proof" that the neck plates are to be regarded as the "labial or microthoracic segment." It seems incredible that any one can seriously put forth as "proof" the mere fact that some investigator has arbitrarily designated the neck plates as the labial segment in his table of the parts of the head, without giving any reasons for so doing, but such seems to be the case, unless these entomologists have reference to some other work which I have not seen. 
Now the neck region of an insect is no more a part of the head capsule than the seven cervical vertebrae of mammals are a part of the skull, and it would therefore be wholly incorrect to say that the head of an insect is composed of six segments, if the sixth, or labial segment, remains behind to form the neck region, which is situated back of the head region. It is thus rather surprising to have these entomologists refer to the head of an insect as composed of six segments (including the labial segment) and in the same breath assert that the neck plates behind the head of such an insect are the labial segment. This is assuredly not in conformity with the laws of physics, which assert that a single body cannot occupy two different positions at one and the same time! If the labial segment is in the head region, it simply cannot be in the neck region behind the head region; and when such embryologists as Heymons, Holmgren, Hirschler, Hoffman, Philiptschenko, Strindberg, and every other recent embryologist, with the exception of Riley, are unanimous in asserting that the labial segment is in the head capsule, it would appear that there is some reason for considering that the labial segment is really in the head capsule and not in the neck region behind the head! Heymons and Holmgren have very carefully traced out the portions of the head which are formed by the embryonic labial segment, and I can see no reason for regarding their work as wholly false, especially since it is borne out by the facts of comparative anatomy and is in accordance with the known zoological phenomena. We are thus justified in stating that the only actual embryological proof thus far brought forward, conclusively demonstrates that the labial segment enters into the composition of the head capsule, and consequently the neck plates must be interpreted as intersegmental plates between the real labial segment and the prothoracic segment, homologous with the other intersegmental plates between the other thoracic segments.

Those who maintain that the neck plates are the labial or microthoracic segment, must bring forward some actual proof for their claim. They must prove the falsity of the embryological evidence brought forward by such embryologists as Holmgren, 19()9, who have shown that the embryonic segment depicted in Fig. 2 is the labial segment, or they must explain in some other way the presence in the head capsule of an 
embryonic segment to which the labium is articulated. They must explain why there are six segments in the head, if the sixth or labial segment remains in the neck region behind the head, to form the cervical sclerites. They must explain the presence in the head region of the labial neuromere. They must explain the lack of segmental structures in the neck region if it is really a "labial or microthoracic segment." They must explain why in the neck region alone in the whole realm of Zoology, a pair of appendages have detached themselves from the supposed segment which originally bore them, and have grafted themselves upon another region; and the description of the hitherto unknown mechanism by which this unique event was brought to pass, will be a distinct contribution to science! Unless they are prepared to admit that the other intersegmental regions (III and V of Fig. 1) were made to appear to be homologous with the neck plates (region I) merely for the purpose of deceiving the unwary, they must grant that these other intersegmental regions between the thoracic segments are also distinct segments, if they claim that the neck region (with which they are in every way homologous) is a distinct segment, either labial or "microthoracic." They must then explain why these new "segments" have no segmental structures, and why embryology offers no indication of their segmental nature. Indeed, the difficulties in the way of accepting the view that the neck plates represent a "labial or microthoracic segment" are so numerous and insuperable, that it is astonishing that any one would deliberately adopt such an utterly unfounded hypothesis and disregard the obvious explanation of the neck plates as an intersegmental region between the true labial segment and the prothorax, just like the other intersegmental region between the thoracic segmentsa view which, unlike the "labial or microthoracic segment" hypothesis, postulates the occurrence of no hitherto unparalleled phenomenon, involves the operation of no inexplicable mechanism, is in complete accord with all of the observed facts of embryology and anatomy, and is the simplest and most logical explanation thus far advanced to account for the occurrence of the neck plates. On this account we are justified in assuming that the neck plates do not represent a segment either labial or "microthoracic," and it is consequently incorrect to designate them as such. 
The term collum is applied to the narrow posterior portion of the head region or to the entire prothorax, by Coleopterologists, and the designation jugulum is applied to the gular region of the head, or to the sides and sternum of the prothorax, so that neither of these terms is available for the true neck region. Since the neck plates are universally designated as the cervical sclerites, the term cervix would be singularly appropriate for the region in question. Dipterologists, however, have very inconsiderately applied the term cervix to the upper portion of the hinder head region in certain flies, and the same term is applied to the posterior constricted neck-like region of the head in other insects, in which the true neck region is also present, so that it would merely create confusion to apply the designation cervix to the true neck region. In order to preserve some form of the term cervix, which is implied in the universally accepted designation cervical sclerites, the neck region was referred to as the veracervix or "cervicum" (Crampton, 19(08-1914, Snodgrass, 1910, Martin, 1916) and the former term has been retained in the present paper.

The intersegmental plates between the other thoracic segments are not preserved in many Pterygotan insects. Traces of them occur between the prothorax and mesothorax of Corydalis cornutus, between the prothorax and mesothorax of the earwig Doru luteipennis (the unknown Forficulid shown in Plate 3, Fig. 19, by Crampton and Hasey, 1915), and in certain Plecoptera and Homoptera. It is in the Apterygotan forms, however, such as Japyx and Eosentomon (Fig. 1) that the intersegmental plates are best preserved between the thoracic segments, and since these are among the most primitive of living insects, we are justified in assuming that the conditions which they present approximate the original one, in many respects.

In Japyx and Eosentomon (Fig. 1) the eutrochantin " $t$ " intervenes between the coxa and the pleural plate "pl." This condition is preserved in the prothoracic region (i. e. in the nonwing-bearing segment, which is consequently the least modified and the most like the segments of the Apterygotan forms) of many of the most primitive Pterygotan forms such as the Plecoptera, Embiids, certain Forficulids (Allostethus) Grylloblattids, Termites, etc., so that I would now consider this condition as representing the original one, and have therefore 
designated the plate " $t$ " (Fig. 1) as the eutrochantin, or true trochantin, instead of the "pseudotrochantin," which I formerly considered it to be (Crampton and Hasey, 1915). This point, however, will be discussed more at length in a subsequent paper.

\section{BIBLIOGRAPHY.}

1893. Banks-Notes on the Mouth Parts and Thorax of Insects, in: Amer. Nat., Vol. 27.

1904. Banks - Notes on the Structure of the Thorax and Maxillae of Insects, in: Proc. Ent. Soc. Washington, Vol. 6, p. 149.

1865. Basch-Untersuch. u. d. Skelet u. d. Muskeln des Kopfes von Termes, in: Zeit. Wiss. Zool., Bd. 15, p. 56.

1905. Bengtsson-Z. Morphologie des Insektenkopfes, in: Zool. Anz. Bd. 29, p.457.

1903. Boerner-Kritische Bemerkungen ueber einige vergl. morphologische Untersuchungen K. W. Verhoeff's, in: Zool. Anz., 26, p. 290.

1904. Boerner-Z. Systematik der Hexapoden, in: Zool. Anz., Bd. 28.

1897. Carriere \& Buerger-D. Entwicklungsgeschichte der Mauerbiene, in: Nova Acta Akad. Leop. Carol. Naturf., Bd. 69, p. 255.

1902. Comstock \& Kochi-The Skeleton of the Head of Insects, in: Amer. Nat.. 26, p. 13.

1908. Crampton-Ein Beitrag z. Homologie d. Thorakal-Skerlite der insckten, Diss. Berlin.

1909. Crampton-A Contribution to the Comparative Morphology of the Thoracic Sclerites of Insects, in: Proc. Acad. Nat. Sciences, Phila., 1909, p. 3.

1914. Crampton-The Ground Plan of a Typical Thoracic Segment in Winged Insects, in: Zool. Anz., 44, p. 56.

1914. Crampton-Notes on the Thoracic Sclerites of Winged Insects, in: Ent. News, 25, p. 5 .

1915. Crampton \& Hasey-The Basal Segments of the Leg in Insects, in: Zool. Jahrb., Abt. Anat., Bd. 39, Heft 1, p. 1.

1908. Desguin-La composition segmentaire du thorax des Insectes, in: Ann. Soc. Ent. Belgique, 52, (3), p. 113.

1907. Enderlein-U. d. Segmental-apotome der Insekten, etc., in: Zool. Anz., Bd., 31.

1899. Folsom-The Segmentation of the Insect Head, in: Psyche, 8, p. 391.

1899. Folsom-The Anat. \& Physiology of the Mouth Parts of the Collembolan Orchesella, in: Bull. Mus. Comp. Zool. Harvard, 36, p. 87.

1900. Folsom-The Development of the Mouth Parts of Anurida, in: Bull. Mus. Comp. Zool. Harvard, Vol. 36.

1904. Haller-U. d. allgemeinen Bauplan des Trachaetensycerebrums, in: Arch. Mikr. Anat., 65, p. 181.

1895. Heymons-D. Segmentirung des Insektenkoerpers, in: Kgl. Preuss. Akad. Wiss. Berlin Anhang.

1895. Heymons-Embryonalentwicklung von Dermapteren u Orthopteren, Jena.

1896. Heymons-B. z. Entwicklungsgeschichte der Insekten Apterygota, in: Sitzb. Akad. Berlin, Bd. 51.

1896. Heymons-G. d. Entwicklung u. d. Koerperbaues von Odonaten u. Ephemeriden, in: Abh. $\mathrm{K}$. Preuss. Akad. Wiss. Berlin, Anhang.

1897. Heymons-U. d. Zusammensetzung des Insektenkopfes, in: Sitzb. Gesell. Naturf. Fr. Berlin.

1905. Heymons-D. Entwicklungsgeschicte von Machilis, in: Verh. Deutsch. Zool. Gesell. Leipzig, 15, p. 123.

1905. Heymons-Review of paper by Verhoeff, 1905, on head of insects, in: Zool. Centralb1., 12, p. 539 .

1909. Hirschler-D. Embryonalentwicklung von Donacia, in: Zeit. Wiss. Zool., XCII, p. 627.

1911. Hoffmann-Z. K. d. Entwicklungsgeschichte der Collembolen, in: Zool. Anz., 37, p. 353 . 
1904. Holmgren-Z. Morphologie des Insektenkopfes, I, in: Zeit. wiss. Zool., 76, p. 439.

1904. Holmgren - Z. Morphologie des Insektenkopfes, II, in: Zool. Anz., Bd, 27.

1907. Holmgren-Z. Morphologie de's Insektenkopfes, III. in: Zool. Anz., 32, p. 73.

1909. Holmgren-Termitenstidien I, Anatomische Untersuchungen.

1913. Hosford-Segmentation of Head of Insects, in: Kans. Univ. Bull., Vol. 8.

1878. Huxley-Manual of the Anatomy of Invertebrate Animals.

1906. Imms-Anatomy and Development of Anurida, in: L. M. B. C. Memoir 13.

1899. Janet-Essai s. 1. constitution morphologie de la tete de l'insecte, Paris.

1593. Kolbe-Einfuehrung i. d. Kenntnisse d. Insekten.

1s93. Korschelt \& Heider-I chrbuch.

1830. Macleay-Explanation o. t. Comparative Anatomy o. t. Thorax in Winged Insects, in: Zool. Jour., Vol. 5, No. 18.

1916. Martin-T. Thoracic and Cervical Sclerites of Insects, in: Ann. Ent. Soc. America, 9, p. 35.

1850. Meinert-S. 1. conformation de la tete etc. chez les insectes, etc., in Ent. Tidsk. arg. 1., p. 147.

1880. Packard-T Number of Segments in the Head of Winged Insects, in: $3 \mathrm{~d}$. Rpt. U. S. Ent. Comm.

1898. Packard-Textbook of Entomology.

1907-1912. Philiptschenko-B. z. K. der Apterygoten in: Zeit. Wiss. Zool., LXXXVIII, p. 99-; XCI, p. 93-; CII, p. 519.

1913. Prell-D. Chitinskelett von Eosentomon, in: Zoologica, Heft 64.

1904. Riley-T. Embryological Development of t. Skeleton o. t. Head of Blatta, in: Amer. Nat., 38, p. 776.

1863. Schaum-U. d. Zusammensetzung d. Kopfes, etc., bei den Insekten, in: Arch. Naturg. Jg. 29, Bd. 1, p. 247.

1902. Silvestri-Einige Bemerkungen u. d. sogenannten mikrothorax d. Insekten, in: Zool. Anz. Bd. 25.

1909. Snodgrass - The Thorax of Insects, etc., in: Proc. U. S. Nat. Mus., Vol. 36.

1910. Snodgrass-The Thorax of the Hymenoptera, in: Ibid. Vol. 39.

1910. Snodgrass -The Anatomy of the Honey-bee, in: U. S. D. A. Bur. Ent. Tech. Ser. No. 18.

1S2S Strauss-Duerkheim-Consid. gen. l'anatomie comparee des animaux articules.

1902. Verhoeff-Ueber Dermapteren. u. ueber den Mikrothorax der Insekten, in: Zool. Anz. Bd. 25.

1902. Verhoeff-U. A. Nerven d. Metacephalsegmentes, etc., in Zool. Anz. Bd. 25.

1903. Verhoeff-B. z. vergl. Morphologie des Thorax der Insekten, etc., in: Nova Acta K. L. C. deuts. Akad. Nat., Bd. LXXXI.

1903. Verhoeff-Intercalarsegmente der Chilopoden, in: Arch. Naturg., Bd. LXIX.

1904. Verhoeff-U. vergl. Morphologie des Kopfes niederer Insekten, in: Nova Acta Kais Leop. Carol. Deutsch. Akad. Naturf. Bd. LXXXIV.

1904. Verhoeff-Z. vergl. Morphologie u. Systematik der Japygiden, in: Ibid, Bd. LXX.

1886. Viallanes-La morphologie du squelette des Insectes, in: Bull. Soc. Phil., Vol. 10.

1904. Voss-U. 1. Thorax von Gryllus, in: Zeit. Wiss. Zool., LXVIII.

1900. Walton-The Basal Segments of the Hexapod Leg, in: Amer. Nat., Vol. 34.

1\$93. Wheeler-contribution to Insect Embryology, in Jour. Morphol., Vol. 7. 